\title{
Pendampingan Pemasaran Industri Lokal Melalui Penggunaan Marketplace untuk Meningkatkan Hasil Produksi pada Masa Pandemi Covid-19 di Desa Sidomukti Lamongan
}

\author{
Fita Faridah, Zafa Wahyu Wulandari \\ Universitas Islam Lamongan \\ E-mail: fitafaridah@unisla.ac.id
}

\begin{tabular}{|c|c|}
\hline Article History: & Abstract: The problems faced by the local industry in \\
\hline Received: Apr 11th 2020 & Sidomukti Village start from sales decline and demand \\
\hline Revised: Aug 30"th 2020 & turnover and conventional marketing method. The \\
\hline Accepted: Nov 30th 2020 & $\begin{array}{l}\text { purpose of this Community Service (PKM) is to provide } \\
\text { an understanding of the meaning and concept of the } \\
\text { marketplace, the benefits and advantages of marketing }\end{array}$ \\
\hline $\begin{array}{l}\text { Keywords: promoting bisnis } \\
\text { product, marketplace, } \\
\text { marketing. }\end{array}$ & $\begin{array}{l}\text { through the marketplace, how the marketplace works, } \\
\text { the manufacturing process, how to register and create a } \\
\text { shop in an online store (market) and to increase } \\
\text { production through the marketplace. The method } \\
\text { applied was service learning which includes three } \\
\text { stages, namely the preparation, presentation, and } \\
\text { reflection stages. The Community Service results in } \\
\text { providing understanding to local industry players in the } \\
\text { Sidomukti village about marketing and selling products } \\
\text { through the marketplace, as well as being able to create } \\
\text { an online shop, promote their products through the } \\
\text { marketplace and increase in sales by } 10 \% \text { of products } \\
\text { from local industries being marketed in several } \\
\text { marketplaces. }\end{array}$ \\
\hline
\end{tabular}

\section{Pendahuluan}

Sejak menyebarnya wabah penyakit pernafasan Covid-19 hampir di semua negara memberikan dampak yang relatif signifikan tidak hanya bagi kesehatan manusia, tetapi juga mengganggu kesehatan ekonomi dunia. ${ }^{1}$ Ekonomi global melambat, terutama menyusul penetapan dari WHO menyebutkan bahwa wabah covid sebagai pandemi yang sangat mempengaruhi dunia usaha². Seperti negara Indonesia mengalami

1 Euzebiusz Jamrozik et al., "Key Criteria for the Ethical Acceptability of Covid-19 Human Challenge Studies: Report of a WHO Working Group," Vaccine (October 28, 2020), accessed December 20, 2020, http://www.sciencedirect.com/science/article/piMokter Hossain, "The Effect of the Covid-19 on Sharing Economy Activities," Journal of Cleaner Production 280 (January 20, 2021): 124782.i/S0264410X20313955.

2 “Dampak Virus Corona ke Industri, PHK Bisa Saja Terjadi," hukumonline.com, last modified March 18, 2020, accessed December 2020, https://www.hukumonline.com/berita/baca/lt5e71e850c93d4/dampak-virus-corona-ke-industri--phkbisa-saja-terjadi/. 
penurunan pertumbuhan ekonominya akibat pandemi virus Corona, pertumbuhan ekonomi bahkan sudah menuju daerah negative pada kuartal kedua tahun $2020^{3}$. Pemerintah berusaha menjaga supaya pertumbuhan dan dampak kesejahteraan tidak menuju pada scenario yang berat, berbagai upaya yang telah dilakukan pemerintah untuk menjaga kestabilan ekonomi, terutama menekan dampak virus corona terhadap dunia industri.

Kementrian Industri menyatakan ada kurang lebih 1 juta industri kecil dan menengah terkena dampak wabah virus corona ${ }^{4}$. Sektor industri lokal atau rumahan adalah sektor yang paling terdepan terdampak wabah Covid-19. Sektor industri lokal terutama industri lokal desa Sidomukti Lamongan mengalami tekanan akibat tidak dapat melakukan kegiatan usaha karena tidak ada kegiatan masyarakat. Dengan adanya anjuran pemerintah untuk melakukan Pembatasan Sosial Berskala Besar (PSBB) dan Work from Home (WFH) membuat daya konsumsi masyarakat mengalami penurunan yang sangat tajam sehingga produksipun tidak dapat maksimal dan distributor tidak bisa menjangkau ke luar kota5. Belakangan ini covid menjadi konsen besar bangsa Indonesia karena permasalahan yang terus ditimbulkannya, Ada banyak kerugian yang disebabkan oleh covid-19 yang berdampak bagi Perekonomian Indonesia. Perekonomian nasional yang lemah sangat mudah terkena dampak negatif sehingga gejolak yang terjadi dalam waktu yang singkat berubah menjadi krisis ekonomi yang terjadi saat ini yang dirasakan oleh negara kita 6 .

Hampir sama dengan persoalan yang dihadapi industri lokal Desa sidomukti mulai dari turunnya omzet penjualan, kesulitan bahan baku, turunnya permintaan, hingga sulitnya pendistribusan ${ }^{7}$. Berdasarkan hasil wawancara dan pengamatan, masalah-masalah yang dihadapi usaha mitra dapat diidentifikasi sebagai berikut: (1) produksi masih terbatas; (2) Pendistribusian masih terbatas (4) Turunnya omset penjualan dan permintaan dan (3) Pemasaran masih konvensional hanya mengandalkan word to mouth. ${ }^{8}$ Berbagai persoalan tersebut diperkirakan akan lebih

3 “Pertumbuhan Ekonomi Indonesia Menuju Fase Negatif Pada Kuartal II | Ekonomi," Bisnis.Com, last modified June 8, 2020, accessed December 2, 2020, https://ekonomi.bisnis.com/read/20200608/9/1250035/pertumbuhan-ekonomi-indonesia-menujufase-negatif-pada-kuartal-ii.

${ }^{4}$ C. N. N. Indonesia, “1 Juta Industri Kecil Dan Menengah Terdampak Virus Corona,” Ekonomi, accessed December 2, 2020, https://www.cnnindonesia.com/ekonomi/20200623135416-92-516453/1juta-industri-kecil-dan-menengah-terdampak-virus-corona.

5 Grahanusa Mediatama, "Sejumlah faktor ini mengancam pertumbuhan ekonomi Indonesia tahun 2020," kontan.co.id, last modified April 30, 2020, accessed December 2, 2020, http://nasional.kontan.co.id/news/sejumlah-faktor-ini-mengancam-pertumbuhan-ekonomi-indonesiatahun-2020.

6 Silpa Hanoatubun, "Dampak Covid - 19 Terhadap Prekonomian Indonesia," EduPsyCouns: Journal of Education, Psychology and Counseling 2, no. 1 (April 14, 2020): 146-153.

${ }^{7}$ Suntono Ita, "Wawancara Personal," Agustus 2020.

${ }^{8}$ Hao Xue and Ronghuo Zheng, "Word-of-Mouth Communication, Noise-Driven Volatility, and Public Disclosure," Journal of Accounting and Economics (September 23, 2020): 101363; Moch Khafidz Fuad Raya, "Pemasaran Pendidikan Islam: Studi Multi Kasus di Universitas Muhammadiyah Malang dan 
parah jika persoalan-persoalan tersebut tidak segera ditangani secara komprehensif sehingga akan berpotensi menurunnya daya jual produk pelaku UMKM di desa ini.

Melihat dampak ekonomi lokal di atas akibat Covid-19, maka pengabdian kali ini difokuskan pada permasalahan yang dihadapi industri lokal dalam hal pemasaran produk. Desa Sidomukti memiliki potensi desa yang sangat besar berdasarkan data desa di sana ada beberapa industri lokal diantaranya adalah industri tikar lipat, industri tas tikar, industri shuttlecock ${ }^{9}$. Kebanyakan para pelaku industri kecil di tempat ini cenderung pasif dalam melakukan kegiatan promosi dan pemasaran produk. Mereka lebih senang memasarkan produk dari words to mouth atau masih bersifat konvensional, dan terlihat masih takut untuk memanfaatkan teknologi digital dan internet. Untuk mengatasi berbagai persoalan yang berhubungan dengan pemasaran maka strategi pemasaran dan konsep pemasaran sangat penting bagi kelangsungan hidup dan perkembangan perusahaan. Maka industri perlu memahami strategi pemasaran untuk meningkatkan jumlah produksi dan keberlangsungan industri10. Untuk itu focus dari pengabdian kali ini yaitu dengan memanfaatan internet di dalam dunia usaha sebagai sarana promosi maupun penjualan. Salah satunya promosi dan penjualan memanfaatkan internet adalah menggunakan marketplace.

Marketplace adalah platform transaksi bisnis online yang menyediakan metode elektrik untuk memfasilitasi transaksi komersil seperti menjual barang, jasa juga informasi secara online antara pembeli dan penjual ${ }^{11}$. Marketplace bertindak sebagai pihak ketiga dalam transaksi online dengan menyediakan tempat berjualan dan fasilitas pembayaran, bisa dikatakan marketplace adalah deparment store online ${ }^{12}$. Pelaku industri lokal dapat merasakan manfaat yang sangat besar dengan menggunakan marketplace dibandingkan secara konvensional, karena dapat mengurangi jumlah biaya dan waktu yang dikeluarkan dalam proses penjualan. Marketplace juga dapat dimanfaatkan oleh industri skala kecil dan menengah, baik untuk promosi maupun

Universitas Nahdlatul Ulama Surabaya" (doctoral, Universitas Islam Negeri Maulana Malik Ibrahim, 2019), accessed July 18, 2020, http://etheses.uin-malang.ac.id/14501/.

9 "Potensi Desa Sidomukti" (Pemerintah Desa Sidomukti, 2019).

10 Rita Zahara and Ayi wahid, Strategi Pemasaran (Yogyakarta: Academisi President University, 2014); Moch Khafidz Fuad Raya, "Marketing Jasa Di Institusi Pendidikan (Analisis Pemasaran Dalam Pendidikan)," FALASIFA: Jurnal Studi Keislaman 7, no. 1 (April 15, 2016): 21-52; Aula Izatul Aini, Muhammad Imam Khaudli, and Ribut Suprapto, "Pemberdayaan Ekonomi Masyarakat Melalui Pemasaran Wisata Kuliner Jajanan Tradisoional Di Desa Cantuk Kabupaten Banyuwangi," Engagement: Jurnal Pengabdian Kepada Masyarakat 2, no. 2 (2018): 168-175.

11 Laith Alrubaiee, Hameed Alshaibi, and Yasir Al-Bayati, "Relationship between B2B ECommerce Benefits, E-Market- Place Usage and Supply Chain Management Relationship between B2B ECommerce Benefits, E-Marketplace Usage and Supply Chain Management," Global Journal of Management and Business Research Volume 12 (June 1, 2012): 22-36; Erik Maier and Jaap Wieringa, "Acquiring Customers Through Online Marketplaces? The Effect of Marketplace Sales on Sales in a Retailer's Own Channels," International Journal of Research in Marketing (September 24, 2020), accessed December 20, 2020, http://www.sciencedirect.com/science/article/pii/S0167811620300835.

12 “Apa Itu Marketplace? Simak Pengertian, Contoh \& Jenisnya," Niagahoster Blog, December 18, 2019, accessed December 2, 2020, https://www.niagahoster.co.id/blog/marketplace-adalah/. 
penjualan. Karena selain biayanya yang cukup murah juga mudah dilakukan serta tidak tergantung oleh waktu. Beberapa jenis marketplace yang dapat dimanfaatkan oleh pelaku industri lokal adalah melalui platform media sosial (semisal facebook marketplace dan Instragram). ${ }^{13}$ Selain itu, bisa menggunkan pasar digital yang sudah familiar di tengah masyarakat, misalnya bukalapak, tokopedia, shopee, Lazada, bibli, JD.ID, Elevenia, Zalora dan lain-lain. Bahkan dengan kehadiran banyak marketplace yang dapat dimanfaatkan sebagai media bisnis, pelaku usaha industri kini tidak perlu lagi memiliki tempat (outlet) atau tempat untuk berjualan yang membutuhkan biaya tinggi. ${ }^{14}$

Berdasarkan pengamatan langsung terhadap pelaku industri lokal yang ada di desa Sidomukti belum sepenuhnya bahkan sama sekali belum memanfaatkan marketplace sebagai media promosi maupun penjualan, untuk itu dengan memanfaatkan marketplace bertujuan untuk dapat meningkatkan penjualan usaha karena produk akan lebih dikenal oleh masyarakat, sehingga dapat meningkatkan kemungkinan terjadinya transaksi. Selain itu manfaat lain yang didapatkan dari marketplace diantaranya masyarakat dapat mengetahui produk yang ditawarkan dengan mudah, bagi calon pembeli dapat melakukan perbandingan dengan produk lain sebelum melakukan transaksi pembelian, peluncuran atau promosi produk baru bisa dilakukan seefektif mungkin, meminimalkan biaya promosi, dan jangkauan pasar atau pangsa menjadi tak terbatas karena bisa diakses darimana saja dan oleh siapa saja ${ }^{15}$. Atas dasar itu pengabdian ini dilakukan untuk membantu industri lokal untuk melakukan penjualan atau promosi melalui marketplace.

\section{Metode}

Kegiatan pengabdian kepada masyarakat ini di laksanakan di Desa Sidomukti Kabupaten Lamongan Propinsi Jawa Timur. Tim Pengabdian ini berkunjung langsung ke lokasi industri lokal masing-masing mitra, dengan skema waktu pendampingan di selasela kesibukan mitra. Metode pelaksanaan pengabdian masyarakat adalah service learning adapun kegiatan ini dilaksanakan melalui tiga tahapan yaitu tahapan persiapan, tahapan melayani dan tahapan refleksi ${ }^{16}$. Adapun dalam tahap melayani Mitra dengan sistem pendampingan yang dilaksanakan secara tutorial. Menurut

13 Alain Yee Loong Chong et al., "The Role of Social Media in Enhancing Guanxi and Perceived Effectiveness of E-Commerce Institutional Mechanisms in Online Marketplace," Information \& Management 55, no. 5 (July 1, 2018): 621-632.

14 Achmad Jamaludin, Zainul Arifin, and Kadarismasn Hidayat, "Pengaruh Promosi Online dan Persepsi Harga terhadap Keputusan Pembelian (Survei Pada Pelanggan Aryka Shop di Kota Malang)" (n.d.): 8.

15 Kadek Surya Mahedy, "Pelatihan Pemanfaatan Media Online Sebagai Sarana Pemasaran Hasil Produksi Bagi Asosiasi Pengrajin Industri Kecil (APIK) Kabupaten Buleleng” (2016): 10.

16 Irene Nusanti, "Strategi Service Learning Sebuah Kajian untuk Mengembangkan Kegiatan Pembelajaran," Jurnal Pendidikan dan Kebudayaan 20, no. 2 (June 16, 2014): 251-260. 
Munir $^{17}$, Interaksi pembelajaran yang dilaksanakan secara tutorial untuk menyampaikan pengetahuan dan informasi secara perorangan atau kelompok berkaitan dengan materi ajar disajikan dalam bentuk unit-unit kecil disertai dengan pertanyaan-pertanyaan. Sehingga memudahkan tim pengabdian kepada masyarakat dalam pendampingan selama 6 hari untuk tiga mitra. Artinya dalam 2 hari tim pengabdian kepada masyarakat melaksanakan pendampingan kepada 1 mitra dengan alokasi waktu 2 jam dalam setiap pertemuan. Adapun tahapan pendampingan tersebut digambarkan ke dalam diagram alir pada gambar 1
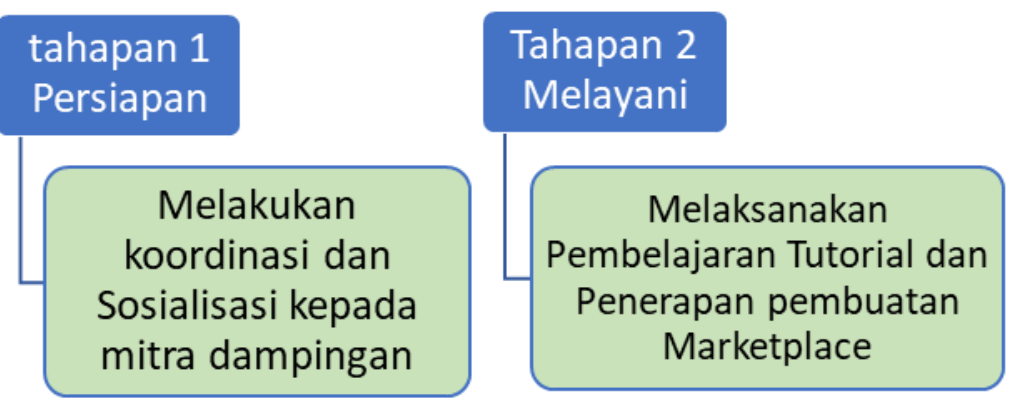

\section{Tahapan 3 \\ Refleksi}

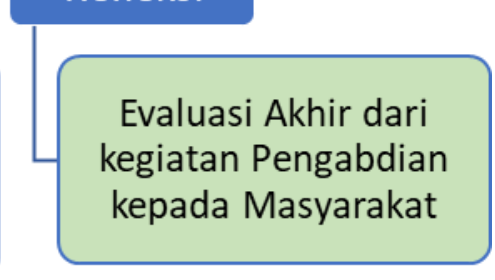

Gambar1. Alur Proses Pelaksanaan Kegiatan Pengabdian Menggunakan Metode Service Learning

Jangka waktu pendampingan dilaksanakan selama tiga minggu, Adapun mitra dampingan sebanyak dua wirausahawan dengan jenis usaha berbeda sebagaimana tersaji dalam table berikut ini:

Tabel 1. Daftar Industri Lokal Desa Sidomukti

\begin{tabular}{ccll}
\hline No & $\begin{array}{r}\text { Nama Pemilik } \\
\text { Industri Lokal }\end{array}$ & Nama Industri Lokal & Alamat Tempat Industri lokal \\
\hline 1 & Bapak Setyo & $\begin{array}{l}\text { Industri Tenun tikar } \\
\text { Lipat }\end{array}$ & $\begin{array}{l}\text { Dusun Kucur Rt. 002 Rtw. 001 } \\
\text { Desa Sidomukti Lamongan Jawa } \\
\text { Timur }\end{array}$ \\
\hline 2 & Bapak Edi Suyanto & $\begin{array}{l}\text { Industri LA COCK } \\
\text { dan MIXMAX }\end{array}$ & $\begin{array}{l}\text { Dusun Kalipang Desa Sidomukti } \\
\text { Lamongan Jawa Timur3 }\end{array}$ \\
& Bapak Setyo & Industri Tas Tikar & $\begin{array}{l}\text { Dusun Kucur Rt. 002 Rtw. 001 } \\
\text { Desa Sidomukti Lamongan Jawa } \\
\text { Timur }\end{array}$ \\
& & & \\
\end{tabular}

${ }^{17}$ Munir, Multimedia Konsep \& Aplikasi Dalam Pendidikan (CV. Alfabeta Bandung, n.d.). 


\section{Hasil}

Kegiatan pengabdian ini dilaksanakan dalam tiga tahap dan dalam durasi waktu 21 hari, tahap awal yang dilakukan yaitu tahapan persiapan. Pada tahapan ini Tim Pengabdian kepada Masyarakat melakukan koordinasi dan sosialisasi program kepada mitra dampingan di Desa Sidomukti Kabupaten Lamongan Propinsi Jawa Timur dengan berkunjung ke lokasi usaha masing-masing secara langsung. Selanjutnya melakukan wawancara secara mendalam untuk mengetahui permasalahan yang dihadapi pelaku industri lokal. Mitra dampingan dalam proses ini dilibatkan secara aktif untuk menemukan masalahnya dalam konteks keluhan mereka terhadap strategi pemasaran yang berdampak pada performa penjualan produk yang mereka hasilkan. Pelibatan masyarakat dalm proses ini, diantaranya dilakukan melalui wawancara kepada beberapa pelaku industri yaitu Ita, Zumaroh, Subekan dan Sutono yang mengeluhkan bahwa omset penjualan selama Covid-19 mengalami penurunan drastis. Salah satu penyebab yang berhasil dihimpun oleh tim, adalah strategi pemasaran yang digunakan para pelaku industri masih bersifat konvensional yaitu dari words to mouth.

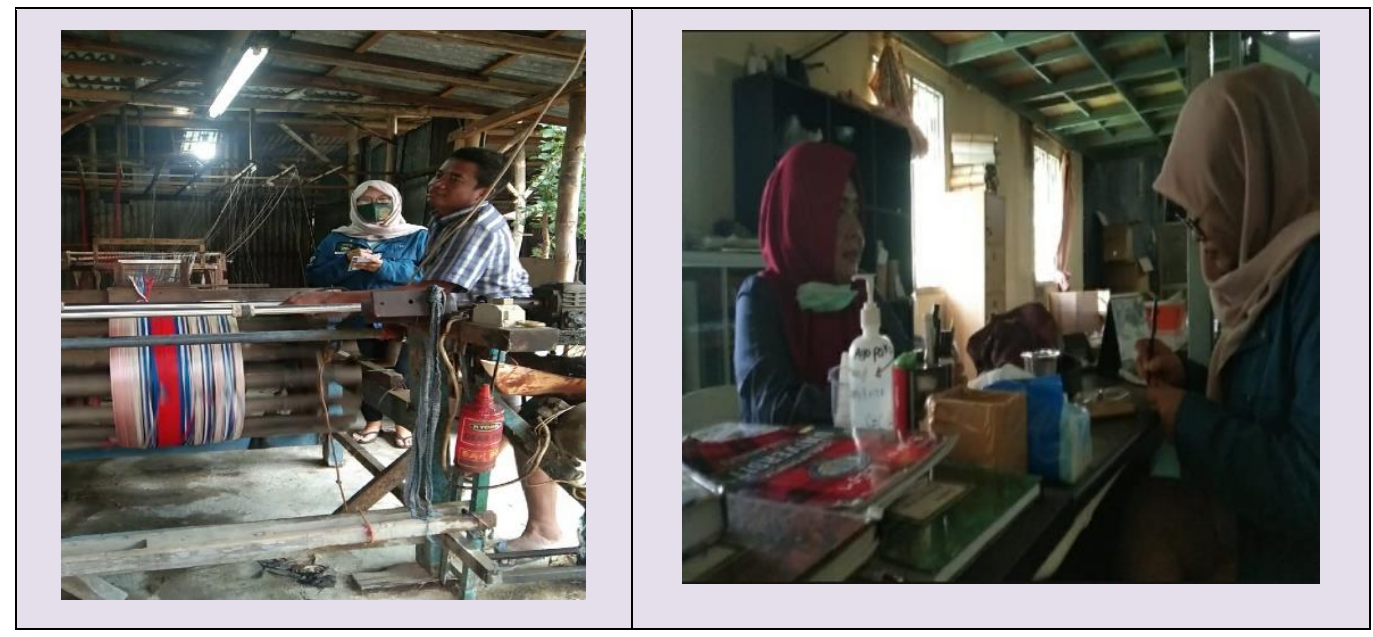

Gambar 2. Wawancara dengan pelaku industri lokal Desa Sidomukti

Setelah inti masalah ditemukan, pada tahap selanjutnya tim memulai tahapan melayani. Pada tahapan ini pelaksanaan kegiatan pengabdian ada beberapa kegiatan yang dilakukan, kegiatan yang pertama adalah pendampingan para pelaku industri dengan cara memberikan pembelajaran secara tutorial. Pada tahapan ini, tim pendamping memberikan pemahaman tentang eksistensi dan pentingnya digital marketplace, sekaligus manfaat dan macam-macamnya. Pengenalan strategi pemasaran dan promosi melalui marketplace dilanjutkan dengan penerapan dan pembuatan toko di beberapa toko online. Pemaparan materi dilaksanakan secara face to face (tatap muka) Materi diberikan dengan metode tutorial dan tanya jawab. 
Tim pada tahap ini memberikan penjelasan terlebih dahulu kepada pelaku industri lokal, kemudian berdiskusi atau tanya jawab terkait dengan materi yang diberikan. Pelaku industri lokal dibimbing cara memasarkan produknya melalui berbagai marketplace seperti bukalapak.com, tokopedia.com, shopee.com dan facebook marketplace. kami Juga mengajarkan dan membimbing mulai dari persiapan awal seperti pembuatan akun email, mendaftar pada marketplace, cara membuka toko pada marketplace. Secara umum pendampingan pada kegiatan pengabdian masyarakat ini meliputi: pembuatan akun email, pendaftaran pada marketplace, pembukaan toko pada marketplace, promosi dan pemasaran pada sosial media (facebook marketplace). Kegiatan tersebut dapat digambarkakn pada Gambar 3 berikut ini.

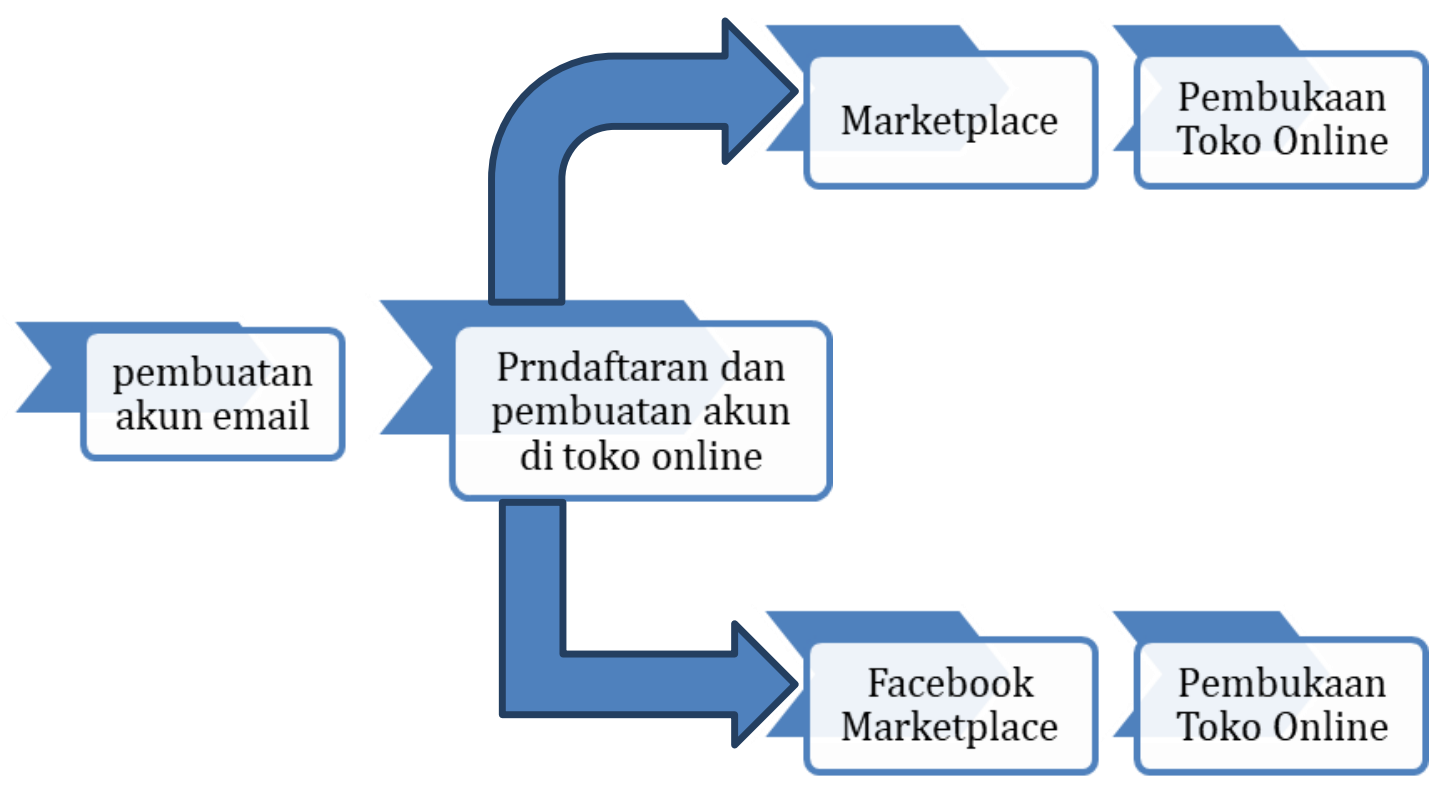

Gambar 3. Alur pendampingan pembuatan toko online

Untuk pendampingan Pembuatan Toko Online diambil tiga contoh marketplace dalam pembuatan toko online yaitu Tokopedia, Shopee dan Facebook. Tokopedia (www.tokopedia.com) merupakan salah satu marketplace atau start up digital terbesar yang ada di Indonesia. Tokopedia menyediakan tempat atau space bagi toko online untuk memasarkan produknya. Tidak hanya cara mendaftarnya mudah, juga memberikan kebebasan pada para penjual online untuk menjual produknya. Selain itu, keamanan juga dapat terjamin karena disediakan rekening bersama sebagai jembatan transaksi antara penjual dan pembeli. 


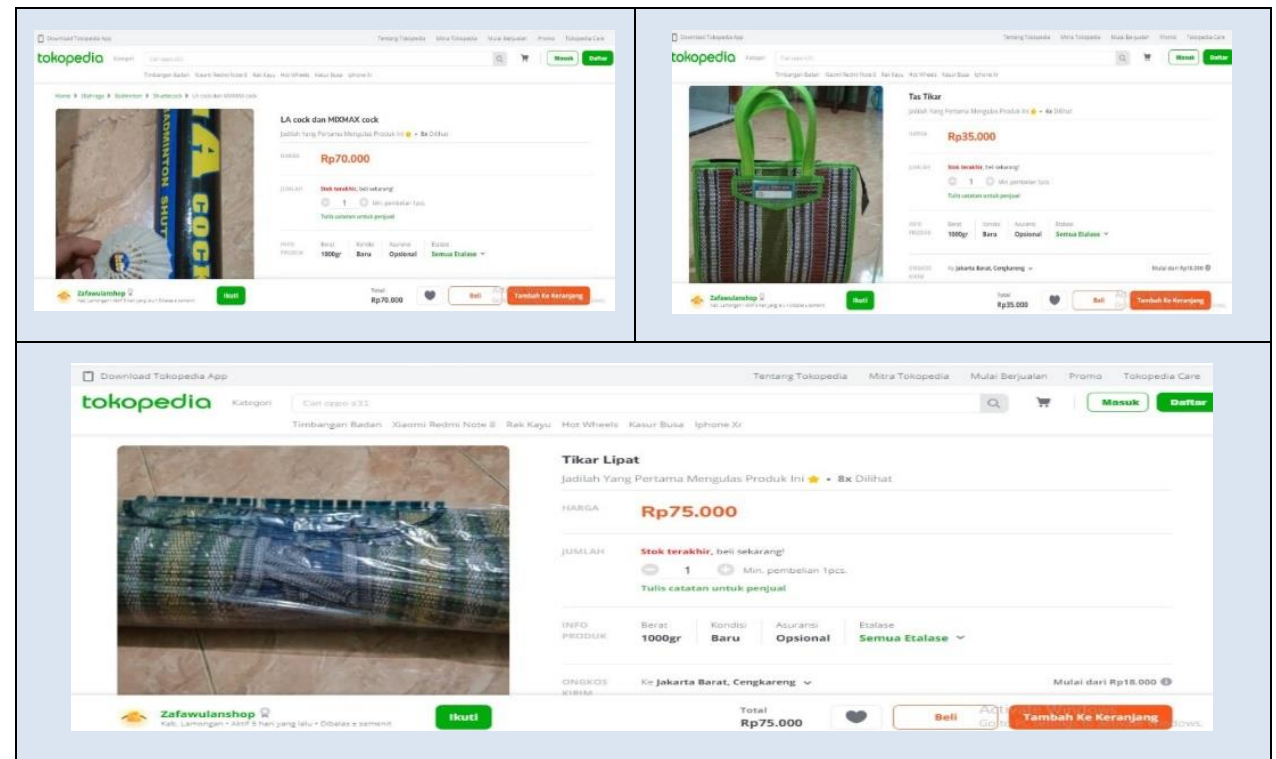

Gambar 4. Tampilan toko online pada Tokopedia

Selain Tokopedia, shopee juga merupakan marketplace terbesar di Indonesia secara konsep dan cara kerja tokopedia dan shopee tidaklah jauh berbeda. Perbedaan hanya terletak pada feature tertentu atau hal baru yang ditawarkan oleh masing-masing marketplace. Cara pendaftaran pada shopee juga tidak jauh berbeda dengan marketplace lainnya. Pendaftar cukup membuka halaman web www.shopee.com dan cari menu daftar.

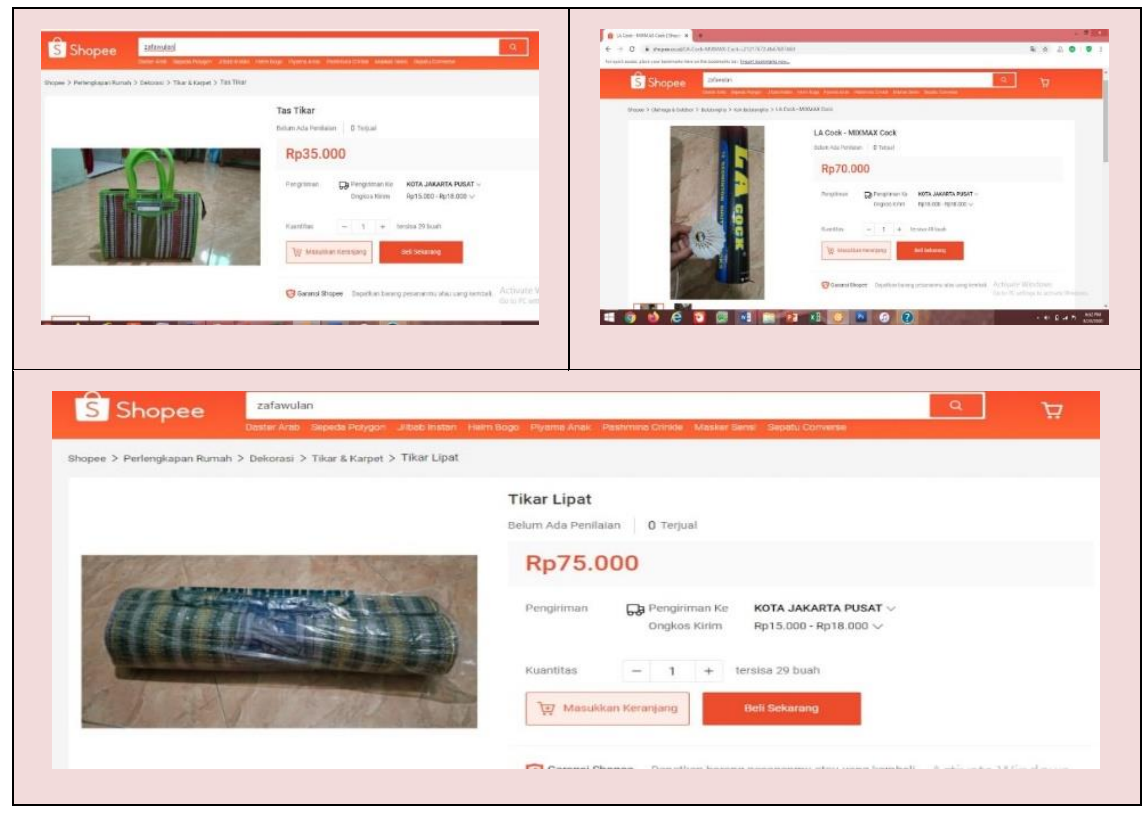

Gambar 5. Tampilan Toko Online pada Shopee 
Pendampingan pembuatan toko yang ke tiga yaitu kita memanfaatka media sosial facebook untuk memasarkan produk hasil industri lokal Desa Sidomukti. Facebook merupakan sosial media yang paling popular di Indonesia dengan pengguna terbanyak selain sosial media lainnya. Selain digunakan sebagai berbagai status atau informasi, gambar dan juga video, Facebook juga kerap digunakan sebagai sarana pemasaran. Terkait dengan transaksi bisa dilakukan secara individu tanpa adanya perantara pihak lain seperti halnya pada marketplace. Pembuatan toko di facebook juga relative mudah asalkan kita sudah punya akun facebook. Pendaftaran bisa dilakukan pada Dekstop dengan membuka laman webnya yaitu www.facebook.com atau dengan mengunduh aplikasinya yang terdapat di Playstore untuk digunakan pada handphone.

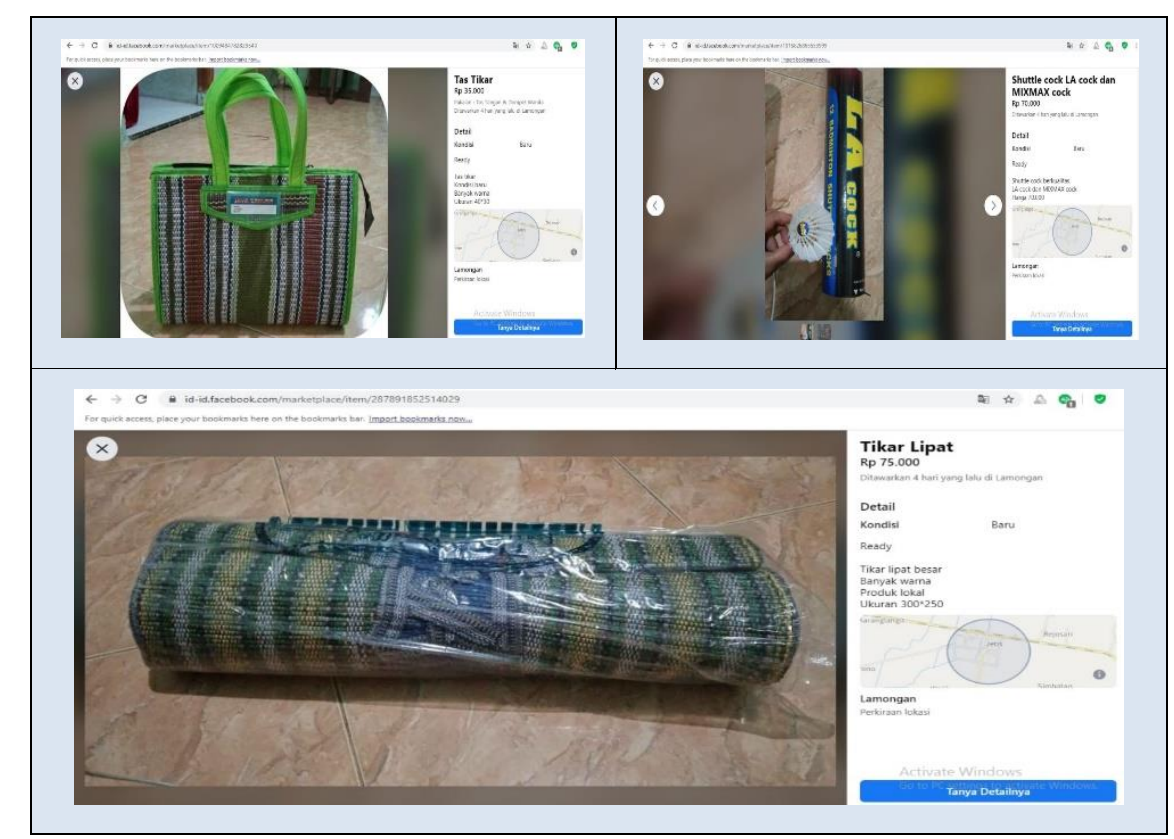

Gambar 6. Tampilan Toko Online pada Facebook

Adapun Tahapan yang terakhir adalah tahapan refleksi, pada tahapan ini dampak penggunaan toko online dalam hal pemasaran dan penjualan produk setelah dievaluasi dari segi peningkatan penjualan para pelaku industri lokal di desa Sidomukti menyatakan ada kenaikan peningkatan penjualan dan produksi sebesar $10 \%$ dari penurunan sebelumnya $20 \%$ hal ini belum meningkat secara signifikan karena usia toko baru satu bulan diperkenalkan melalui marketplace. Dari segi implementasi tahap layanan melalui tutorial dan praktek langsung promosi produk melalui media sosial, didapatkan hasil bahwa model pendampingan ini sangat bermanfaat bagi mereka. Hal ini sebagaimana diungkapkan oleh Setyo dan Edi yang menyatakan bahwa model promosi produk melalui marketplace ini sangat membantu mereka, mengingat mereka belum pernah sama sekali melakukan promosi bagi produk hasil usahanya. Melalui marketplace, mereka dapat melalukan promosi dengan kreatif dengan low budget. Dari 
proses pendampingan di atas, pendampingan dalam promosi produk melalui media marketplace memiliki manfaat yang sangat baik bagi mitra dampingan. Dengan pendekatan service learning, mitra dampingan telah mampu membuat promosi yang baik serta telah merasakan ada peningkatan volume penjualan produk-produk usaha mereka dengan low budget.

Melalui pendampingan pembuatan toko online pada pelaku UMKM di Desa Sidomukti ini, pada akhirnya melahirkan satu pranata sosial baru yaitu tumbuhnya satu sistem pemasaran digital yang sudah mulai dirasakan dampaknya oleh para pelaku ekonomi mikro, serta telah berhasilnya mengoperasionalkan secara mandiri tentang bagaimana memasarkan produksinya melalui beberapa platform marketplace. Sehingga hal ini berimplikasi pada segmentasi pasar yang semakin luas dan potensi penjualan yang meningkat.

\section{Diskusi}

Pada tahap pertama yaitu tahap persiapan tim pengabdian melakukan koordinasi, sosialisasi serta melakukan wawancara secara mendalam. Wawancara mendalam adalah teknik pengumpulan data untuk menemukan permasalahan dan mengetahui hal-hal mendalam yang bersumber pada informan secara langsung 18 . Wawancara mendalam digunakan untuk mengetahui permasalahan secara terperinci dan mendalam yang dihadapi para pelaku usaha atau industri. Berdasarkan hasil wawancara tersebut sejak adanya wabah Covid-19 berbagai permasalahan muncul menurunkan produksi industri sampai menurunnya omset penjualan. Berdasarkan keterangan mitra bahwa rata-rata penurunan omset dan produksi mengalami penurunan 20\% setelah Covid-19. Kegiatan ini dimulai dengan memberikan pertanyaan kepada mitra apa saja permasalahan yang dihadapi peserta terkait tentang promosi dan pemasaran terutama pada saat wabah covid-19, hampir seluruh peserta mempunyai permasalahan yang sama akan terbatasnya akses penjualan terutama dalam hal promosi dan pemasaran. Dengan bertanya permasalahan mereka kita akan memberikan solusi kepada para pelaku industri bahwa dengan adanya marketplace ini akan memudahkan mereka dalam hal memasarkan produk untuk meningkatkan produksi.

Pada tahapan melayani dilaksanakan secara tutorial dan tanya jawab, pemberian materi secara tutorial lebih efektif dan memberikan pemahaman lebih cepat terutama bagi mitra pengabdian. Pada tahapan ini ada beberapa target yang dicapai dalam pembelajaran secara tutorial meliputi sebagai berikut: (a) Pelaku industri lokal memahami tentang pengertian dan konsep marketplace; (b) pelaku industri lokal mengetahui manfaat dan keunggulan pemasaran melalui marketplace; (c) pelaku industri memahami cara kerja marketplace (toko online, dan sosial media); (d) pelaku industri lokal mengetahui proses pembuatan marketplace; (e) mengetahui bagaimana

18 L. Gelling, “Qualitative Research,” Qual. Res., 2015. 
cara mendaftar dan membuat toko pada toko online (marketplace). Dengan adanya pemberian materi secara tutorial pelaku industri dibimbing dan mempraktekkan pembuatan marketplace secara langsung. Marketplace yang dipilih untuk memasarkan hasil produksi yaitu bukalapak.com, tokopedia.com, shopee.com dan facebook karena ketiganya dianggap marketplace yang paling popular di Indonesia sehingga dapat meningkatkan penjualan ${ }^{19}$.

Pada tahapan akhir yaitu refleksi, pada tahap ini kita melakukan evaluasi terhadap seluruh kegiatan kami. Dari proses implementasi tahap layanan melalui tutorial dan praktek langsung promosi produk melalui marketplace, didapatkan hasil bahwa model pendampingan ini sangat bermanfaat bagi mereka ${ }^{20}$. Mitra dampingan juga menjelaskan bahwa promosi melalui marketplace ini terbukti mampu meningkatkan volume penjualan produk mereka dibanding bulan-bulan sebelumnya, walaupun kenaikan belum meningkat secara signifikan karena toko belum genap satu bulan dibuat di marketplace. Dari proses pendampingan di atas, pendampingan dalam promosi produk melalui marketplace memiliki manfaat yang sangat baik bagi mitra dampingan. Dengan pendekatan service learning, mitra dampingan telah mampu membuat promosi yang baik serta telah merasakan ada peningkatan volume penjualan produk-produk usaha mereka dan secara otomatis mampu meningkatkan produksi hasil industri mereka.

Ada beberapa alasan dalam penggunaan marketplace sebagai sarana promosi karena alasan sebagai berikut: (1) biaya minimal; (2) mudah dikenali; dan (3) area distribusi global. Promosi produk melalui marketplace juga bisa membangun komunikasi yang baik dengan pelanggan mereka. ${ }^{21}$ Melalui digital marketplace, pelaku UMKM juga bisa melakukan brand image produknya masing-masing dengan kemasan, cara memotret produk dan mempromosikannya melalui narasi-narasi yang menarik. ${ }^{22}$

Selain itu, signifikansi teoritik dari pengabdian ini adalah eksistensi pasar online sangat memiliki peluang besar dalam memperkuat posisi UMKM dalam pasar regional, nasional bahkan global. Hal ini disebabkan di Indonesia prospek e-commerce sangat cerah karena konsumsi internet penduduk Indonesia sangat tinggi dan kecenderungan

19 Elly Antika and Titik Ismailia, "Pemanfaatan E-Commerce Untuk Meningkatkan Pemasaran Produk Ud Wahana Mandiri Sejahtera Jember" (2016): 4.

20 "Kedudukan Refleksi Dalam Proses Pembelajaran," Pusat Inovasi Pembelajaran, n.d., accessed December 2, 2020, http://pip.unpar.ac.id/publikasi/buletin/sancaya-volume-03-nomor-01-edisi-januarifebruari-2015/kedudukan-refleksi-dalam-proses-pembelajaran/.

21 Dedi Rianto Rahadi and Leon Andretti Abdillah, "The Utilization of Social Networking as Promotion Media (Case Study: Handicraft Business in Palembang)," in SESIND02013 Conference. Seminar Nasional Sistem Informasi Indonesia (SESINDO) (Bali: arXiv.org, 2013), accessed May 31, 2020, http://arxiv.org/abs/1312.3532.

22 Fadhlir Rahman et al., "Strategi Umkm Dalam Membangun Brand Toko Online di Marketplace (Studi Pada Komunitas Tokopedia Di Kota Bekasi)," Jurnal Administrasi Bisnis (JAB)/Vol 53, no. 1 (2017): 39-48. 
berallih mengguakan platform digital dalam memenuhi kebutuhan. ${ }^{23}$ Disamping itu yang tidak kalah penting, bahwa dengan adanya marketplace berbasis media sosial dan platform yang sudah besar, maka pelaku UMKM lebih mudah memasarkan produknya, karena bisa berimprovisasi dengan cara memotretnya secara bagus serta dilengkapi dengan promosi melalui caption yang baik. Melalui pemasaran media online, pelaku usaha mikro juga diuntungkan karena mempermudah konsumen yang sedang mencari barang-barang yang telah diproduksinya ${ }^{24}$ karena terpotongnya distribusi penjualan, sehingga produksi barang langsung bisa diterima konsumen dari produsennya langusung. ${ }^{25}$

Dengan makna lain, pendampingan kepada pelaku UMKM di Desa Sidomukti ini tak hanya terbatas soal pemasaran produk yang dilakukan secara online, namun juga turut memancing calon konsumen yang lebih banyak karena akses informasi lebih luas di akses melalui platform marketplace yang sudah mereka kuasai dengan baik. ${ }^{26}$ Bahkan pada posisi tertentu, melalui media digital mempermudah proses transaksi dan pelayanan produk sehingga performa penjualan bisa dikontrol, dievaluasi sekaligus ditingkatkan kebutuhannya secara real time. ${ }_{-}^{27}$

\section{Kesimpulan}

Berdasarkan hasil pengabdian masyarakat yang telah kita lakukan terhadap industri lokal di Desa Sidomukti dapat disimpulkan bahwa: (1) pengabdian ini telah memberikan pemahaman kepada pelaku industri lokal di desa Sidomukti tentang pemasaran dan penjualan produk melalui marketplace; (2) para pelaku industri lokal mampu membuat toko online dan promosi produk mereka melalui bukalapak.com, tokopedia.com, shopee.com dan facebook secara mandiri; dan (3) produk dari industri lokal di pasarkan di beberapa marketplace yang ada di Indonesia. Bagi pelaku industri lokal agar menjaga kepercayaan pelanggan dengan cara menjaga kualitas atau mutu produk dan pelayanan yang baik. Pengabdian yang sangat terbatas ini hanya mampu menyelesaikan satu persoalan saja yaitu menyelesaikan masalah pemasaran dan promosi produk untuk meningkatkan hasil produksi terutama di masa pandemic seperti ini dan permasalahan yang lain yang telah diutarakan diatas akan kami jadikan

23 Rustina Untari and Ridwan Sanjaya, "Penggunaan E-Marketplace Untuk Pengrajin Tenun Sumba," Jurnal Ecodemica 4, no. 1 (2020): 1-16.

${ }^{24}$ Muhammad Andrean, Eka Saputra, and Tony Sugiarso, "Perancangan Dan Implementasi Sistem Informasi E-Marketplace Untuk Katering," Jurnal Teknologi Informasi 5, no. 2 (2017): 1-10.

25 Arie Yandi Saputra Deni Apriadi, "E-Commerce Berbasis Marketplace Dalam Upaya Mempersingkat Distribusi Penjualan Hasil Pertanian," Jurnal RESTI (Rekayasa Sistem dan Teknologi Informasi) 1, no. 2 (2016): 131-136.

26 Putu Artaya and Tubagus Purworusmiardi, "Efektifitas Marketplace Dalam Meningkatkan Konsentrasi," Universitas Narotoma Surabaya, no. April (2019).

27 Tommi Suryanto, "Penerapan E-Marketplace Pada Distro Silver Squad," Konferensi Nasional Sistem Informasi (KNSI) 2018 0, no. 0 (2018): 8-9. 
bahan referensi untuk kegiatan pengabdian lain dengan permasalahan dan solusi yang sama.

\section{Pengakuan}

Kami mengucapkan terima kasih sebesar-besarnya kepada Litbang Pemas dan Universitas Islam Lamongan atas support dalam pendanaan pengabdian masyarakat ini hingga terlaksana dengan baik dan juga kami ucapkan kepada seluruh pihak yang terlibat secara langsung dan tidak langsung atas suksesnya program kegiatan pengabdian masyarakat ini.

\section{Daftar Referensi}

Aini, Aula Izatul, Muhammad Imam Khaudli, and Ribut Suprapto. "Pemberdayaan Ekonomi Masyarakat Melalui Pemasaran Wisata Kuliner Jajanan Tradisoional Di Desa Cantuk Kabupaten Banyuwangi." Engagement: Jurnal Pengabdian Kepada Masyarakat 2, no. 2 (2018): 168-175.

Alrubaiee, Laith, Hameed Alshaibi, and Yasir Al-Bayati. "Relationship between B2B ECommerce Benefits, E-Market- Place Usage and Supply Chain Management Relationship between B2B E-Commerce Benefits, E-Marketplace Usage and Supply Chain Management." Global Journal of Management and Business Research Volume 12 (June 1, 2012): 22-36.

Andrean, Muhammad, Eka Saputra, and Tony Sugiarso. "Perancangan Dan Implementasi Sistem Informasi E-Marketplace Untuk Katering." Jurnal Teknologi Informasi 5, no. 2 (2017): 1-10.

Antika, Elly, and Titik Ismailia. "Pemanfaatan E-Commerce Untuk Meningkatkan Pemasaran Produk Ud Wahana Mandiri Sejahtera Jember” (2016): 4.

Artaya, Putu, and Tubagus Purworusmiardi. "Efektifitas Marketplace Dalam Meningkatkan Konsentrasi." Universitas Narotoma Surabaya, no. April (2019).

Chong, Alain Yee Loong, Ewelina Lacka, Li Boying, and Hing Kai Chan. "The Role of Social Media in Enhancing Guanxi and Perceived Effectiveness of E-Commerce Institutional Mechanisms in Online Marketplace." Information \& Management 55, no. 5 (July 1, 2018): 621-632.

Deni Apriadi, Arie Yandi Saputra. "E-Commerce Berbasis Marketplace Dalam Upaya Mempersingkat Distribusi Penjualan Hasil Pertanian.” Jurnal RESTI (Rekayasa Sistem dan Teknologi Informasi) 1, no. 2 (2016): 131-136.

Hanoatubun, Silpa. "Dampak Covid-19 terhadap Prekonomian Indonesia." EduPsyCouns: Journal of Education, Psychology and Counseling 2, no. 1 (April 14, 2020): 146- 
153.

Hossain, Mokter. "The Effect of the Covid-19 on Sharing Economy Activities." Journal of Cleaner Production 280 (January 20, 2021): 124782.

Indonesia, C. N. N. "1 Juta Industri Kecil Dan Menengah Terdampak Virus Corona." Ekonomi. Accessed December 2020. https://www.cnnindonesia.com/ekonomi/20200623135416-92-516453/1juta-industri-kecil-dan-menengah-terdampak-virus-corona.

Ita, Suntono. "Wawancara Personal," Agustus 2020.

Jamaludin, Achmad, Zainul Arifin, and Kadarismasn Hidayat. "Pengaruh Promosi Online Dan Persepsi Harga Terhadap Keputusan Pembelian (Survei Pada Pelanggan Aryka Shop di Kota Malang)" (n.d.): 8.

Jamrozik, Euzebiusz, Katherine Littler, Susan Bull, Claudia Emerson, Gagandeep Kang, Melissa Kapulu, Elena Rey, et al. "Key Criteria for the Ethical Acceptability of Covid-19 Human Challenge Studies: Report of a WHO Working Group." Vaccine (October 28, 2020). Accessed December 20, 2020. http://www.sciencedirect.com/science/article/pii/S0264410X20313955.

Mahedy, Kadek Surya. "Pelatihan Pemanfaatan Media Online sebagai Sarana Pemasaran Hasil Produksi Bagi Asosiasi Pengrajin Industri Kecil (APIK) Kabupaten Buleleng" (2016): 10.

Maier, Erik, and Jaap Wieringa. "Acquiring Customers Through Online Marketplaces? The Effect of Marketplace Sales on Sales in a Retailer's Own Channels." International Journal of Research in Marketing (September 24, 2020). Accessed December 20, 2020. http://www.sciencedirect.com/science/article/pii/S0167811620300835.

Mediatama, Grahanusa. "Sejumlah faktor ini mengancam pertumbuhan ekonomi Indonesia tahun 2020." kontan.co.id. Last modified April 30, 2020. Accessed December 2, 2020. http://nasional.kontan.co.id/news/sejumlah-faktor-inimengancam-pertumbuhan-ekonomi-indonesia-tahun-2020.

Munir. Multimedia Konsep \& Aplikasi Dalam Pendidikan. CV. Alfabeta Bandung, n.d.

Nusanti, Irene. "Strategi Service Learning Sebuah Kajian untuk Mengembangkan Kegiatan Pembelajaran." Jurnal Pendidikan dan Kebudayaan 20, no. 2 (June 16, 2014): 251-260.

Rahman, Fadhlir, M Kholid, Mawardi Fakultas, and Ilmu Administrasi. "Strategi Umkm Dalam Membangun Brand Toko Online di Marketplace (Studi Pada Komunitas Tokopedia Di Kota Bekasi)." Jurnal Administrasi Bisnis (JAB)/Vol 53, no. 1 (2017): 39-48.

Raya, Moch Khafidz Fuad. "Marketing Jasa Di Institusi Pendidikan (Analisis Pemasaran 
Dalam Pendidikan)." FALASIFA : Jurnal Studi Keislaman 7, no. 1 (April 15, 2016): 21-52.

Raya, Moch Khafidz Fuad. "Pemasaran Pendidikan Islam: Studi Multi Kasus di Universitas Muhammadiyah Malang dan Universitas Nahdlatul Ulama Surabaya." Doctoral, Universitas Islam Negeri Maulana Malik Ibrahim, 2019. Accessed July 18, 2020. http://etheses.uin-malang.ac.id/14501/.

Suryanto, Tommi. "Penerapan E-Marketplace Pada Distro Silver Squad." Konferensi Nasional Sistem Informasi (KNSI) 2018 0, no. 0 (2018): 8-9.

Untari, Rustina, and Ridwan Sanjaya. "Penggunaan E-Marketplace Untuk Pengrajin Tenun Sumba." Jurnal Ecodemica 4, no. 1 (2020): 1-16.

Xue, Hao, and Ronghuo Zheng. "Word-of-Mouth Communication, Noise-Driven Volatility, and Public Disclosure." Journal of Accounting and Economics (September 23, 2020): 101363.

Zahara, Rita, and Ayi wahid. Strategi Pemasaran. Yogyakarta: Academisi President University, 2014.

"Apa Itu Marketplace? Simak Pengertian, Contoh \& Jenisnya." Niagahoster Blog, December 18, 2019. Accessed December 2, 2020. https://www.niagahoster.co.id/blog/marketplace-adalah/.

"Dampak Virus Corona ke Industri, PHK Bisa Saja Terjadi." hukumonline.com. Last modified March 18, 2020. Accessed December 2, 2020. https://www.hukumonline.com/berita/baca/lt5e71e850c93d4/dampak-viruscorona-ke-industri--phk-bisa-saja-terjadi/.

"Kedudukan Refleksi Dalam Proses Pembelajaran." Pusat Inovasi Pembelajaran, n.d. Accessed December 2, 2020. http://pip.unpar.ac.id/publikasi/buletin/sancayavolume-03-nomor-01-edisi-januari-februari-2015/kedudukan-refleksi-dalamproses-pembelajaran/.

"Pertumbuhan Ekonomi Indonesia Menuju Fase Negatif Pada Kuartal II | Ekonomi." Bisnis.Com. Last modified June 8, 2020. Accessed December 2, 2020. https://ekonomi.bisnis.com/read/20200608/9/1250035/pertumbuhanekonomi-indonesia-menuju-fase-negatif-pada-kuartal-ii.

“Potensi Desa Sidomukti." Pemerintah Desa Sidomukti, 2019. 